\title{
SOLAR ENERGY FLUX INCIDENT ON A HORIZONTAL PLANE OF DIFFERENT EGYPTIAN LOCATIONS FOR AGRICULTURAL APPLICATIONS
}

\author{
El-Sayed, A. S. ${ }^{1}$; Hassanain, A. A. ${ }^{2}$; Mosalhi, S. M. ${ }^{3}$
}

\begin{abstract}
Solar energy is the main parameter, which affects both photovoltaic pumps and crops evapo-transpiration. A micro computer program derived for mapping the incident solar energy over Egypt $\left(22^{\circ}\right.$ to $32^{\circ}$ and $24^{\circ}$ to $38^{\circ}$ latitude and longitude angles, respectively). The derived model transforms the solar altitude angle to solar radiation intensity, which integrated between sunrise and sunset to compute the incident solar energy. The model was validated with the measured solar energy with average deviation percent of $-3.5 \%$. The daily average solar energy flux incident on a horizontal plane was $5.72 \mathrm{kWh} / \mathrm{m}^{2} /$ day.
\end{abstract}

Keywords: Solar energy over Egypt, Agricultural application

\section{INTRODUCTION}

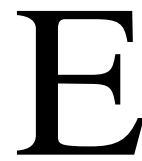

gypt is one of the richest countries that receives an abundant amount of solar energy, varies between 7 and $8 \mathrm{kWh} / \mathrm{m}^{2} /$ day (Moharm, 1993). Egypt receives abundant amount of solar radiation approximately $5.77 \mathrm{kWh} / \mathrm{m}^{2} /$ day $\left(20.772 \mathrm{MJ} / \mathrm{m}^{2} /\right.$ day). Solar energy determination either measured by weather stations or predicted is required for the agricultural purposes such as solar water pumping, crop evapo-transpiration, and the region suits cultivate a specified crop. The solar constant ranged between $1367 \mathrm{Wm}^{-2}$ and $1413 \mathrm{Wm}^{-2}$ (ASHRAE, 2005).

Monthly horizontal solar radiation for the Arab region based on the measurements obtained from the ground stations over Cairo were 2.80, $4.00,5.30,6.30,7.50,7.80,7.60,6.94,5.80,4.70,3.30$, and 2.60 $\mathrm{kWh} / \mathrm{m}^{2} /$ day form January till December, respectively. Whereas, the monthly averages solar energy flux incident on a horizontal plane over some Egyptian cities such as Aswan, Bahtim, Giza, and Mersa-Matruh were 6.87, 5.63, 5.53, and $5.45 \mathrm{kWh} / \mathrm{m}^{2} /$ day (Sayigh, 1987).

\footnotetext{
${ }_{1}^{1}$ Prof. of Agr. Eng., Suez-Canal Univ.

${ }^{2}$ Assoc. Prof. of Agr. Eng., Suez-Canal Univ. $\quad{ }^{3}$ Agr. Eng.
} 
Solar energy on a horizontal plane over Egypt was analyzed by Shaltout and Hassen, (1990) using satellite images. The satellite images verified by that obtained from 10 meteorological ground stations. They found that, the amount of the direct solar radiation over the north to south Egypt varied from 3.7 to $5 \mathrm{kWh} / \mathrm{m}^{2} /$ day in winter and it has a narrow range of 8 to $8.3 \mathrm{kWh} / \mathrm{m}^{2} /$ day in summer. Also, the diffuse radiation decreases from the north to the south Egypt, and the tabulated data indicted that, the daily average solar radiation was $7.05 \mathrm{kWh} / \mathrm{m}^{2} /$ day. Based on the measurement of eleven ground weather stations, the daily average solar radiation flux incident on a horizontal surface over Egypt is 5.29 $\mathrm{kWh} / \mathrm{m}^{2} /$ day; with an average sunshine duration of $9.95 \mathrm{~h}$ (ESRA, 1991). The objective of this study is to develop a simple micro-computer program written by MatLab, which derived to determine the solar energy over different Egyptian locations for the agriculture applications.

\section{MATERIALS AND METHODOLOGY}

A computer model has been developed and functioned for computing the solar energy flux incident on a horizontal plane of different Egyptian locations based on MatLab program. The obtained results of solar energy flux incident on different locations of Egypt were validated with the measured. It was also used to determine the sunrise and sunset times and correlated the solar altitude angle with the total amount of solar radiation flux incident. The correlation process is repeated for each day and latitude over Egypt to assess the solar energy flux incident over Egypt. The solar energy flux incident on a horizontal plane simplified flowchart for MaLab program showed in Fig. (1).

\section{Program Algorithm}

- The starting day and the end day were fed to the developed mathematical model from 1 ( $1^{\text {st }}$ January) to 366 ( $31^{\text {st }}$ December), (366 days), also, the lower and higher latitude (degree). Based on the input parameters, the program calculated the required output.

- The solar declination angle $(\delta)$ as a function of the day number $(n d)$, was computed from the following equation (ASHRAE, 2005):

$$
\delta=23.45 \sin [0.9863(284+n d)]
$$


- Sunset hour angle $\left(\omega_{s}\right)$ which is a function of latitude angle $(\phi)$ and declination angle $(\delta)$ it was computed from equations (2):

$$
\omega_{s}=\cos ^{-1}[-\tan \phi \tan \delta]
$$

- The maximum number of bright sunshine hours $(N)$ can be estimated from the following equation:

$$
N=\frac{2}{15} \cos ^{-1}[-\tan \phi \tan \delta]
$$

- The sun rise time was computed using the following equation:

$$
\text { sunrise time }=6+\frac{1}{15} \sin ^{-1}[-\tan \phi \tan \delta]
$$

- The sunrise angle was computed using the following equation:

$$
\text { sunrise angle }=15 * \text { [sun rise time }-12]
$$

- The sunset time equals, the day light hour $(N)$ plus the sunrise time.

- Solar altitude angle $(\alpha)$ is a function of solar declination angle $(\delta)$, latitude angle $(\phi)$, and solar hour angle $(\omega)$ it was computed as:

$$
\alpha=\arcsin [\cos (\delta) \cos (\phi) \cos (\omega)+\sin (\phi) \sin (\delta)]
$$

MatLab program was run to compute the solar altitude angle using equation (6) from sunrise to sunset time. In this model a constant to transform solar altitude angle into solar radiation $\left(\mathrm{Wm}^{-2}\right)$ is executed. The following sequence of steps is used to extract the referred constant:

The solar altitude angles were computed with one year duration for location where the Met-One weather station latitude of $31.45^{\circ}$ and longitude of $33.0^{\circ}$. This step requires adjusting the code of the developed Micro-Solar program in a convenient way. In the same location, the MetOne station records hourly incident solar radiation on a horizontal plane. The result from this step is shown in Fig. (2) for the solar altitude angle ( $x$-axis) and the solar radiation ( $y$-axis), under clear and unclear sky conditions. The proposed model estimates solar energy for the clear day's 
conditions, Fig. (2) can not be used to estimate solar radiation, where the coefficient of determination is 0.6 .

Data of the clear hours were selected from the previous figure for further manipulation. The clear hour is the hour in which the quotient of the terrestrial radiation on a horizontal plane (from station readings) by the extraterrestrial radiation (from equation 7) (i.e. clearness index) $\geq 0.80$. The extraterrestrial radiation $\left(G_{o}\right)$ is a function of solar constant $\left(G_{s c}=\right.$ $1367 \mathrm{Wm}^{-2}$ ), day number ( $n d$ ) is given by equation (7). Again, the code of Micro-Solar program was adjusted in a convenient way to calculate the extraterrestrial radiation on a horizontal plane.

$$
G_{o}=G_{s c}\left[1+0.033 \cos \frac{360 n d}{365}\right][\cos (\delta) \cos (\phi) \cos (\omega)+\sin (\phi) \sin (\delta)]
$$

Fig. (3) shows the solar altitude angles against the measured solar radiation on a horizontal plane by weather station (for clear sky hours). For programming simplicity, data in Fig. (3) was expressed as linear regression with determination coefficient of 0.96 . The inclination of the best fitting line in the figure (i.e. 13.23) is the extracted coefficient, which can multiplied by solar altitude angle to obtain horizontal solar radiation in clear sky conditions in unit of $\mathrm{Wm}^{-2}$. The computed data were flowed as represented in the following flowchart.

\section{Solar radiation on tilted plane}

Hourly clearness index, $k_{T}$ is the ratio of solar radiation on a horizontal plane that is predicted by the model $(G)$ to extraterrestrial radiation on a horizontal plane $\left(G_{o}\right)$, it was computed according to (Duffie and Beckman, 1991):

$$
k_{T}=\frac{G}{G_{o}}
$$

Ratio of diffuse $\left(G_{d}\right)$ to the total solar radiation $(G)$ in a horizontal plane is computed using the equation of (Erbs et al. 1982) as:

$$
\frac{G_{d}}{G}=\left\{\begin{array}{lr}
1.0-0.09 k_{T} & \text { For }_{T} \leq 0.22 \\
0.9511-0.1604 k_{T}+4.388 k_{T}^{2} & \\
-16.638 k_{T}^{3}+12.336 k_{T}^{4} & \text { For } 0.22<k_{T} \leq 0.80 \\
0.165 & \text { For } k_{T}>0.80
\end{array}\right.
$$


Under clear sky conditions, the third statement of equation (10) was used i.e. ratio of diffuse to total solar radiation on a horizontal plane is 0.165 . The tilt factor $\left(R_{b}\right)$ can be computed from the following equation (Duffie and Beckman, 1991):

$$
R_{b}=\frac{\cos (\vartheta)}{\cos (Z)}
$$

Where: $(Z)$ is zenith angle, which equals (90-solar altitude angle). $(\theta)$ is the incidence angle; it is calculated according to the tracking and orientation technique (Duffie and Beckman, 1991):

The isotropic diffuse model of Liu and Jordan, (1963) was used to calculate total solar radiation on a tilted and oriented plane $\left(G_{t}\right)$ as follows:

$$
G_{t}=G_{b} R_{b}+G_{d}\left(\frac{1+\cos (\beta)}{2}\right)+G \rho\left(\frac{1-\cos (\beta)}{2}\right)
$$

Where: $\left(G_{b}\right)$ is beam solar radiation on a horizontal surface, $(\beta)$ is the tilt angle of the surface plane, $(\rho)$ is the ground reflectance. The terms of equation (11) are beam, sky diffuse, and ground reflected solar radiation flux incident on the tilted plane, respectively.

\section{Model Validation:}

To validate the computation model, a comparison was carried out between the computed solar energy against that obtained from measurements campaigns of eleven ground meteorological stations (for the agricultural purposes). These stations were selected to cover most locations of Egypt as shown in table (1).

Table (1): The selected meteorological stations to validate the computer model (ESRA, 1991)

\begin{tabular}{|l|l|l|l|l|}
\hline Stations & Lat $(\phi),{ }^{0} \mathrm{~N}$ & Long $\left(L_{l o c}\right),{ }^{\mathbf{0}} \mathrm{E}$ & Elev $(\mathrm{sl}), \mathrm{m}$ & Climatic district \\
\hline Aswan & 23.96 & 32.78 & 200.0 & Upper Egypt \\
\hline Kharga & 25.45 & 30.53 & 77.8 & Western Desert \\
\hline Assiut & 27.05 & 31.01 & 234.7 & Middle Egypt \\
\hline Hurghada & 27.28 & 33.76 & 1.0 & Red Sea \\
\hline Abu Rudeis & 28.88 & 33.18 & 18.9 & Sinai \\
\hline Cairo & 30.08 & 31.28 & 34.4 & Cairo \\
\hline Bahteem & 30.13 & 31.25 & 16.6 & Nile Delta \\
\hline El-Tahrir & 30.65 & 30.7 & 15.6 & Nile Delta \\
\hline El-Arish & 31.26 & 33.75 & 15.0 & Mediterranean \\
\hline Mersa Matruh & 31.33 & 27.21 & 38.3 & Mediterranean \\
\hline Sidi Barani & 31.63 & 25.46 & 21.0 & Mediterranean \\
\hline
\end{tabular}




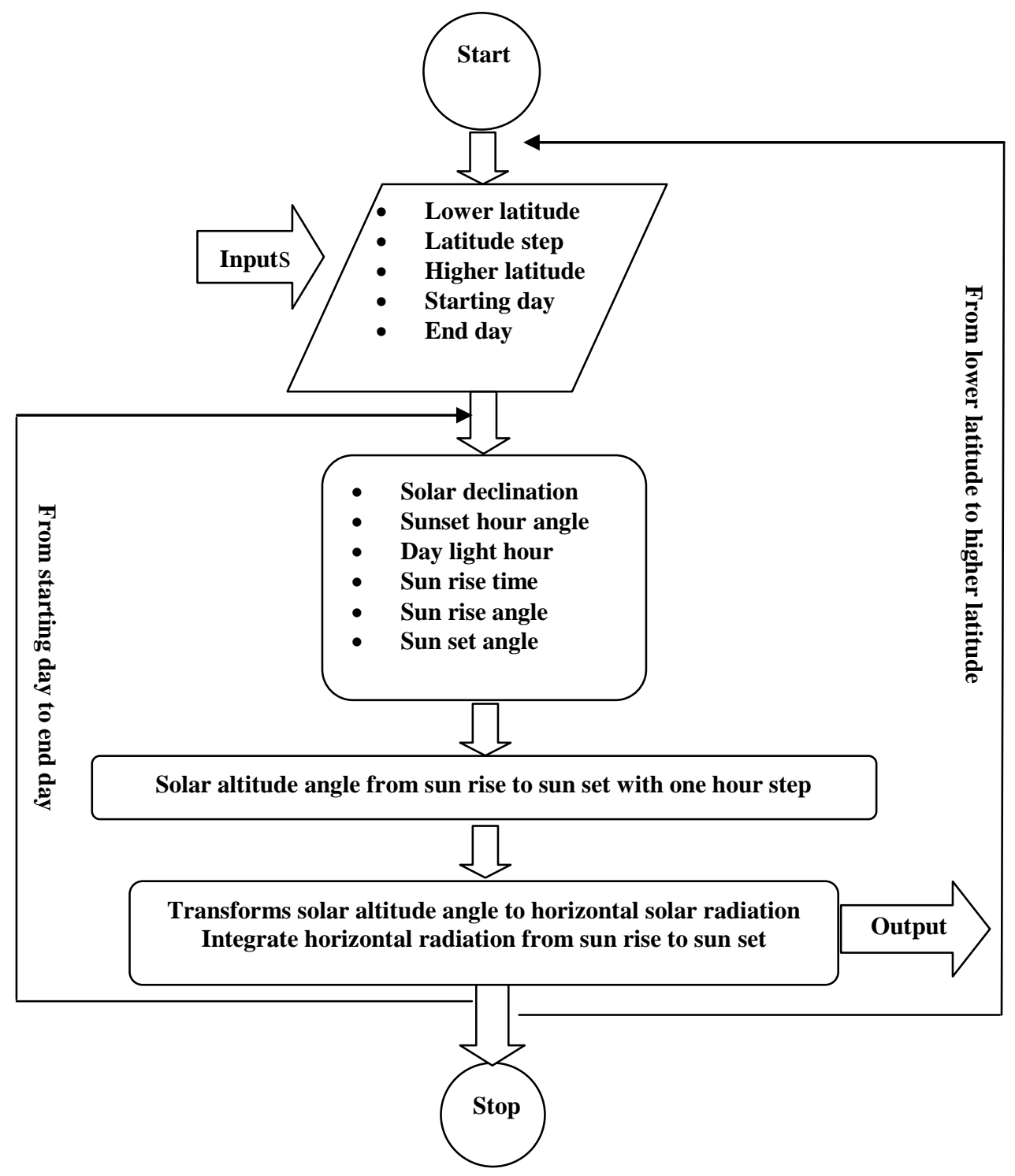

Fig. (1): Simplified flowchart for MatLab program 


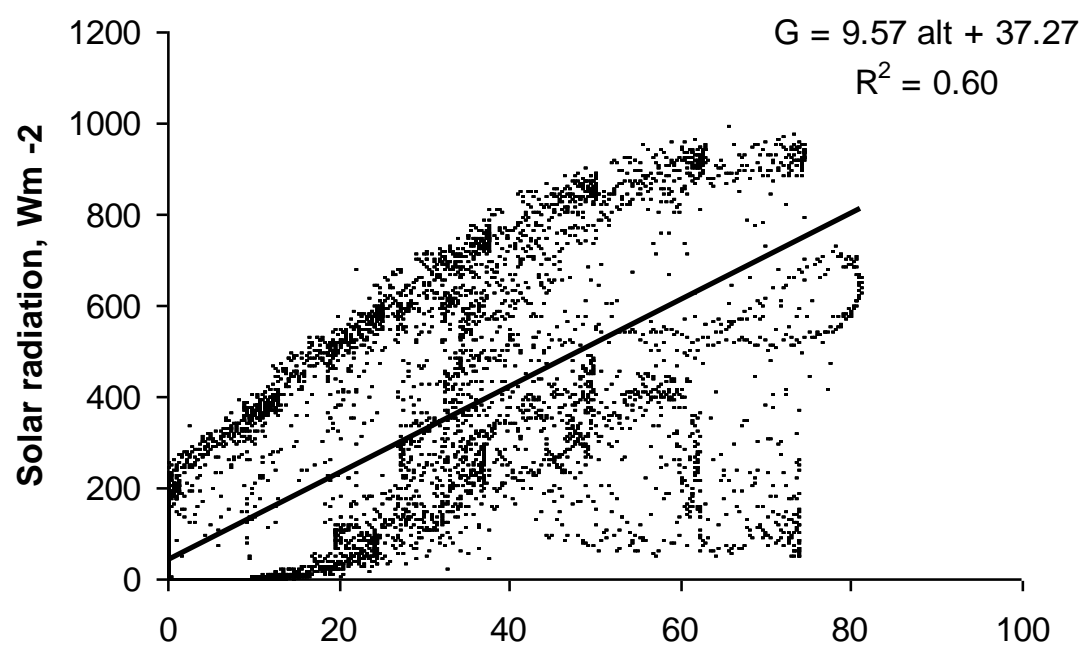

Solar altitude, degree

Fig. (2): Solar radiation measured on a horizontal plan versus solar altitude angle

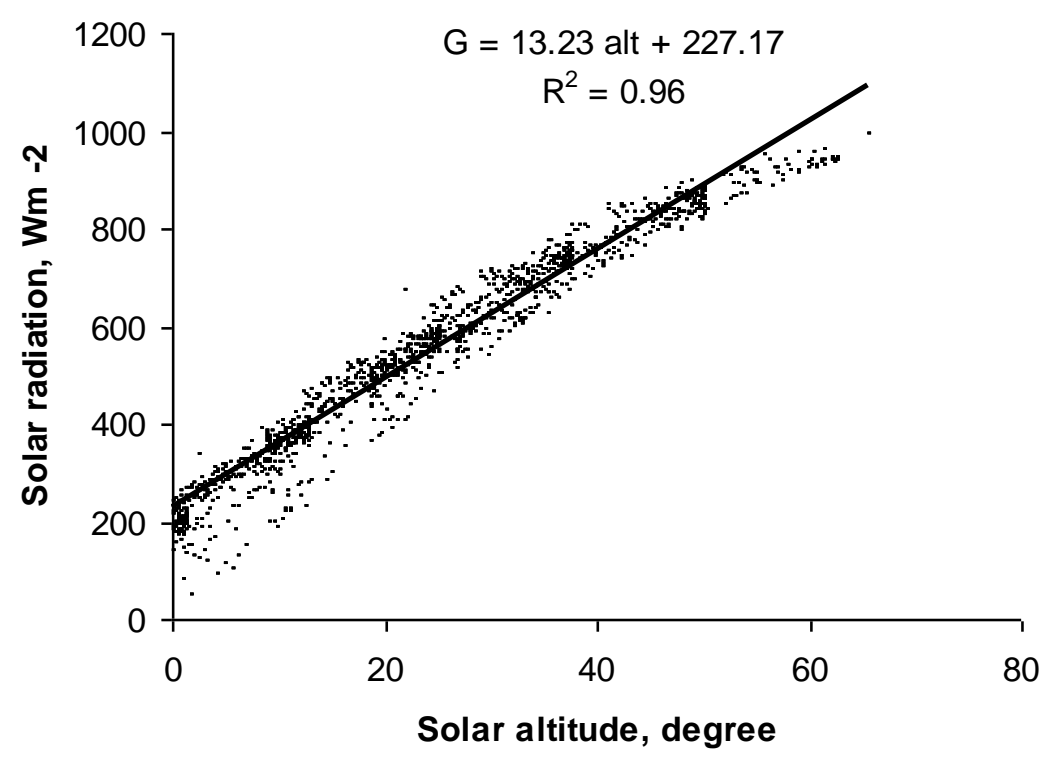

Fig. (3): Solar radiation measured on a horizontal plane under clear sky conditions versus solar altitude angle 


\section{Agricultural Application}

Incident solar energy on the PV-module or arrays eliminates the generated electricity which affects the photovoltaic pumps. The pumped water may be used to provide the irrigation water for different agricultural crops. Photovoltaic pumping system composes solar cells, which operating electric motors coupled with hydraulic pumps for supplying water demands as a function of crop evapo-transpiration. The photovoltaic pumps output (in terms of water flow rate and head) and crop evapo-transpiration are mainly directly proportional to solar energy, which is modeled herein.

Ambient air temperature inversely affects photovoltaic pumps outputs and directly crop evapo-transpiration. Wind speed directly affects photovoltaic pumps outputs (due to its cooling effect on solar panel) and crop evapo-transpiration. Relative humidity inversely affects crop evapotranspiration.

The Penman-Monteith equation requires four climatic parameters to model crop evapo-transpiration, such as solar energy, ambient temperature, wind speed and relative humidity. Penman-Monteith equation calculates the crop evapo-transpiration (ETc) based on climatic parameters using (initial, mid season, and lat season) crop coefficients (Allen et al., 1998).

\section{Measurements}

Met-One weather station was utilized in this study, the station has data storage (model 455A) with internal memory sufficient to collect data for a period of 200 days when data is recorded on an hour basis, or can be read or monitored on site. The system was pre-tested and certified before installation. It composed sensors for measuring:

The model 096-1 solar radiation sensor is an accurate and sensitive sensor using a LI-COR sensing element and designed for the continuous measurement of solar radiation. The sensor calibrated against an Eppley pyranometer by the manufacture under natural daylight clear conditions with an absolute accuracy of $\pm 5 \%$ and response time of 10 microseconds.

Thermocouple (Model 060A-2) was used for air temperature measurements within range between -50 to $+50^{\circ} \mathrm{C}$ with an accuracy of \pm 
$0.1^{\circ} \mathrm{C}$. The sensor is always mounted in a radiation shield to minimize errors caused by solar thermal radiation heating. Sensor produces resistance change inversely proportional to temperature.

Wind sensor (Model 034A) was used for wind speed measurements within range between 0 to $49.1 \mathrm{~m} / \mathrm{s}$ with accuracy of $0.11 \mathrm{~m} / \mathrm{s}$ at wind speed less than $10.14 \mathrm{~m} / \mathrm{s}$ and $\pm 1.1 \%$ at wind speed greater than $10.14 \mathrm{~m} / \mathrm{s}$. Relative humidity sensor (Model 083D) was used for relative humidity measurements within range between 0 to $100 \%$ with accuracy of $\pm 2 \%$ at relative humidity between $10-100 \%$.

Rainfall sensor (Model 370C/372C) was used for rainfall measurements with accuracy of $\pm 1 \%$ at rainfall between $1-3$ inches at $70^{\circ} \mathrm{F}$.

Evaporation gauge sensor (Model 255-100 analog output) was used for evaporation measurements. The evaporation gauge provides an electrical signal proportional to the water level inside evaporation pan.

\section{RESULTS AND DISCUSSIONS}

The output resulted from the computation model is shown in Fig. (4) for the solar energy over Egypt between latitudes of $22^{\circ}$ (south) and $32^{\circ}$ (north). Solar energy over latitude of $22^{\circ}$ was found to be higher than that over the latitude of $32^{\circ}$. The average solar energy all the year round over the two latitudes was 6.00 and $5.41 \mathrm{kWh} / \mathrm{m}^{2} /$ day, respectively. Minimum solar energy of $3.67 \mathrm{kWh} / \mathrm{m}^{2} /$ day in January, 1 over latitude of $22^{\circ}$ was computed. This energy was increased to reach its maximum of 7.31 $\mathrm{kWh} / \mathrm{m}^{2} /$ day in (June, 21), and then decreased to the end of the year till reach $3.60 \mathrm{kWh} / \mathrm{m}^{2} /$ day. This refers to the high solar radiation intensity and day length in summer months than in winter months. Meanwhile for latitude of $32^{\circ}$, and for the same period respectively the corresponded amounts were $2.69,7.45,2.69 \mathrm{kWh} / \mathrm{m}^{2} /$ day. The same trend was observed for all latitudes between $22^{\circ}$ to $32^{\circ}$ as shown in Fig. (4). Wide variation of solar energy over Egypt from south to north at the beginning of the first month of the year as shown in Fig. (4). This difference tends to be reduced in and around the mid of the year (June, July, and August). Again this difference increase till the end of the year. The incident solar energy is a function of latitude and day number within the year $(n d)$. A gradient of solar energy from the south to the north of Egypt observed in Fig. (5). Average solar energy was found to be 6.00, 5.95, 5.90, 5.84, 
$5.79,5.73,5.67,5.60,5.54,5.48$, and $5.41 \mathrm{kWh} / \mathrm{m}^{2} /$ day consequently for latitude from $22^{\circ}$ to $32^{\circ}$, respectively. Difference between yearly average solar energy over southern and northern locations of Egypt was found to be $10.9 \%$. The daily average solar energy over Egypt (the average of the previous solar energies) was $\mathbf{5 . 7 2 4 6} \mathrm{kWh} / \mathrm{m}^{2} /$ day. This average encourages the different applications in the agricultural sector of Egypt.

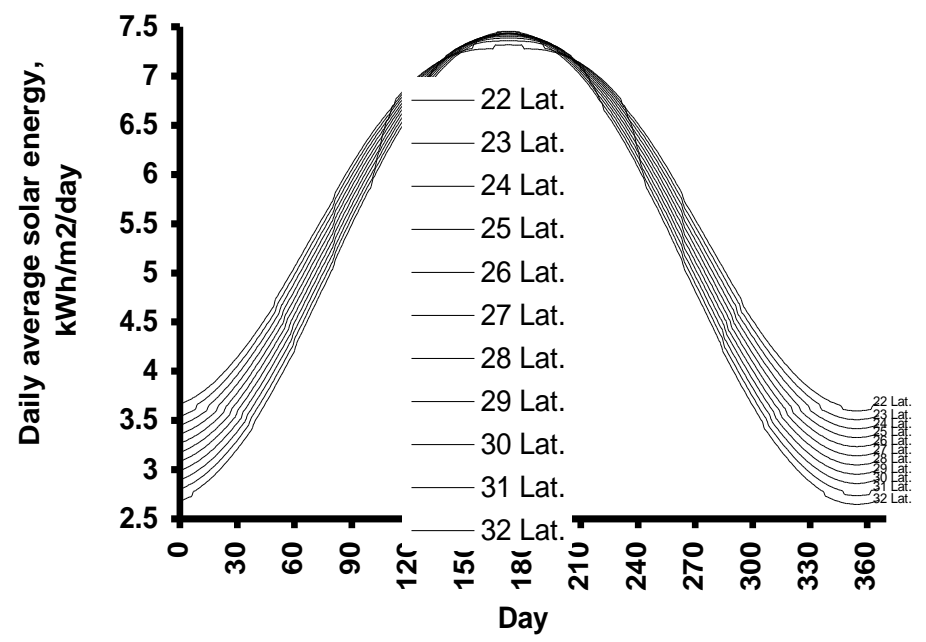

Fig. (4): Daily average solar energy over Egypt

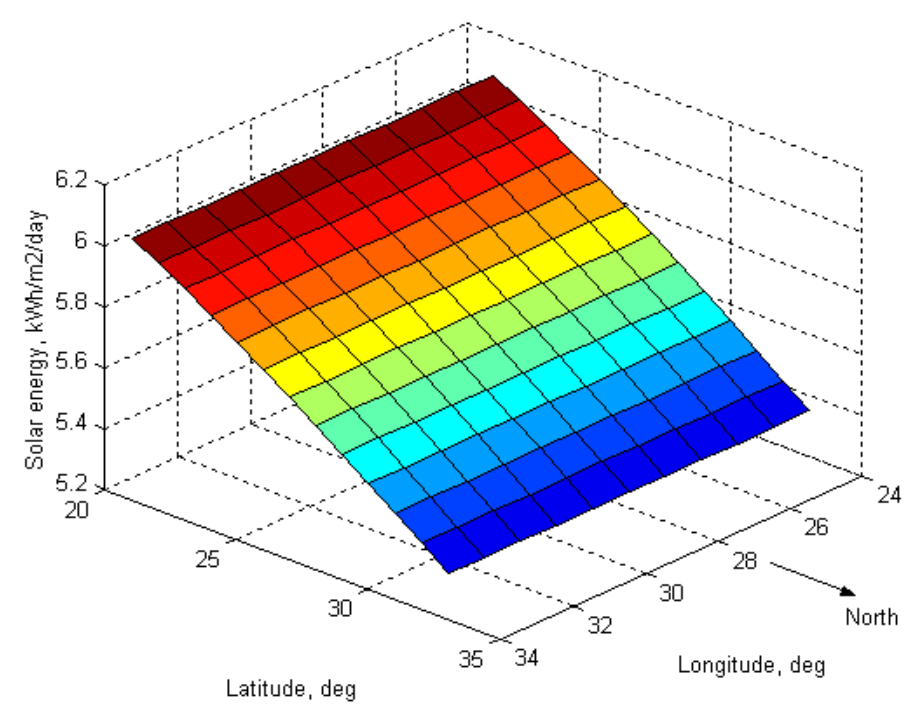

Fig. (5): Daily average solar energy for different latitudes over Egypt 


\section{Model Validation:}

Measured (Mes.) and predicted (Pre.) daily average solar energy of the ground station and the output from the developed computer program are summarized and listed in table (2).

Table (2): Measured and predicted solar energy over Egypt (ESRA, 1991):

\begin{tabular}{|c|c|c|c|c|c|c|c|c|c|c|c|}
\hline 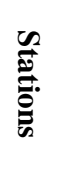 & 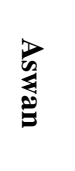 & 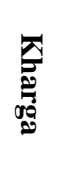 & $\begin{array}{l}\text { 点 } \\
\stackrel{0}{E}\end{array}$ & 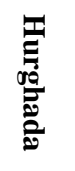 & 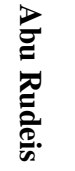 & ڤ્犬 & 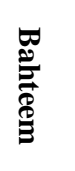 & 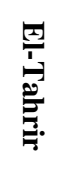 & 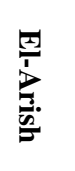 & 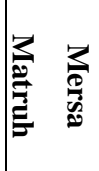 & 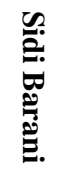 \\
\hline Mes. & 6.70 & 6.30 & 5.99 & 6.38 & 6.18 & 5.21 & 5.51 & 5.36 & 5.53 & 5.60 & 5.50 \\
\hline Pre. & 5.91 & 5.82 & 5.73 & 5.72 & 5.62 & 5.54 & 5.54 & 5.50 & 5.46 & 5.46 & 5.44 \\
\hline
\end{tabular}

Fig. (6) illustrates average solar energy for the measured and predicted and percentage deviation between them for each ground station. The ground stations were arranged on the figure from the lower latitude (Egypt south) to higher latitude (Egypt north), the deviation of the predicted from the measured was calculated using the following equation:

$$
\text { Deviation, } \%=\frac{\text { Pre. }- \text { Mes. }}{\text { Mes. }} \times 100
$$

It was observed from the figure:

Maximum solar energy for measured and predicted was 6.7 and 5.9 $\mathrm{kWh} / \mathrm{m}^{2} /$ day over Aswan, respectively. Meanwhile, the minimum measured solar energy was 5.21 over Cairo; [this might be referred to the low clearness index].

The daily average measured and predicted solar energy were 5.84 and $5.61 \mathrm{kWh} / \mathrm{m}^{2} /$ day, respectively for the eleven selected locations. The deviation between measured and predicted was underestimating of -3.5 $\%$. Maximum deviation was found to be $-11.8 \%$ in Aswan.

The computation model was found well estimating the solar energy either for the southern part of Egypt (with deviation of -8.6\%) or the northern of Egypt (with deviation of $-0.33 \%$ ). 


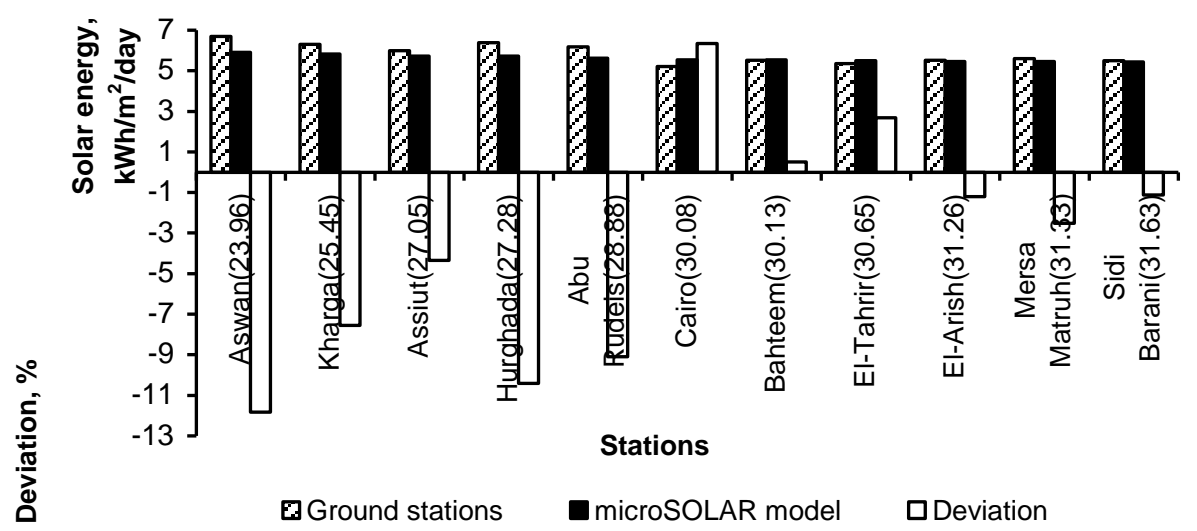

Fig. (6): Validation between the model and the ground stations, and the contrast deviation, \%

The average solar energy over calro tor the all months around the year from January till December were predicted over Cairo using Micro-Solar program and was validated and compared against that collected data for long term (nearly 15 years) by Sayigh, (1987) . Fig. (7) shows linear regression between the proposed model and ground station measurements. The coefficient of determination, the slop of best fitting line, the intersection with $y$-axis were found to be $0.97,0.95$, and 0.36 which encourages using the proposed model.

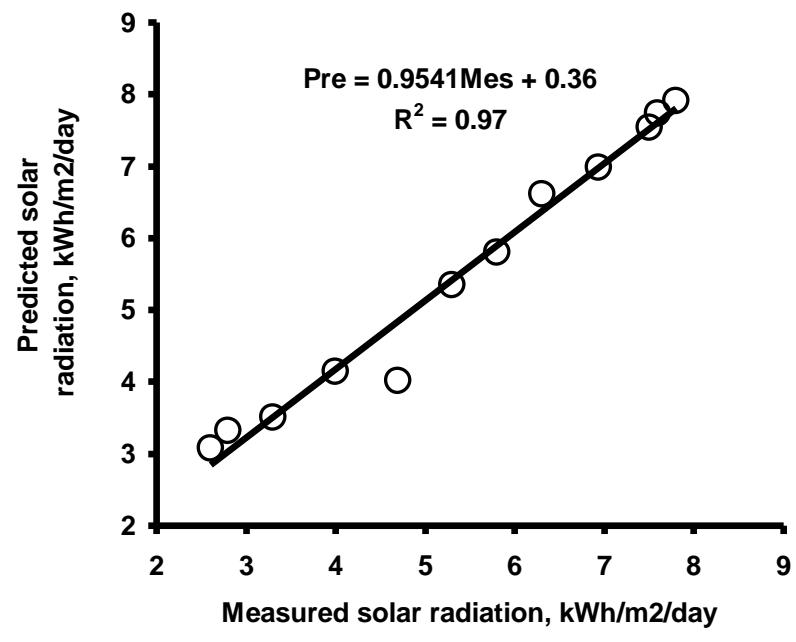

Fig.[7]: Monthly average solar energy over Cairo as computed from the model Vs. measured solar radiation 
The hourly reference evapo-transpiration (ETo) for one year duration was computed for the following two cases:

Case 1: Using four climatic parameters (solar energy, ambient temperature, wind speed, and relative humidity) measured by Met-One weather station, which located in BerAlabed $\left(33.0^{\circ}\right.$ longitude and $31.45^{\circ}$ latitude), Egypt.

Case 2: The hourly reference evapo-transpiration for the same site was computed using the same measured of the three climatic parameters (ambient temperature, wind speed, and relative humidity) beside the predicted solar energy resulted from the proposed model.

The two previous cases are daily plotted in Fig. (8). Coefficient of determination between the two previous cases was found to be 0.94, which refers that the proposed model can be efficiently used in approximating crop evapo-transpiration.

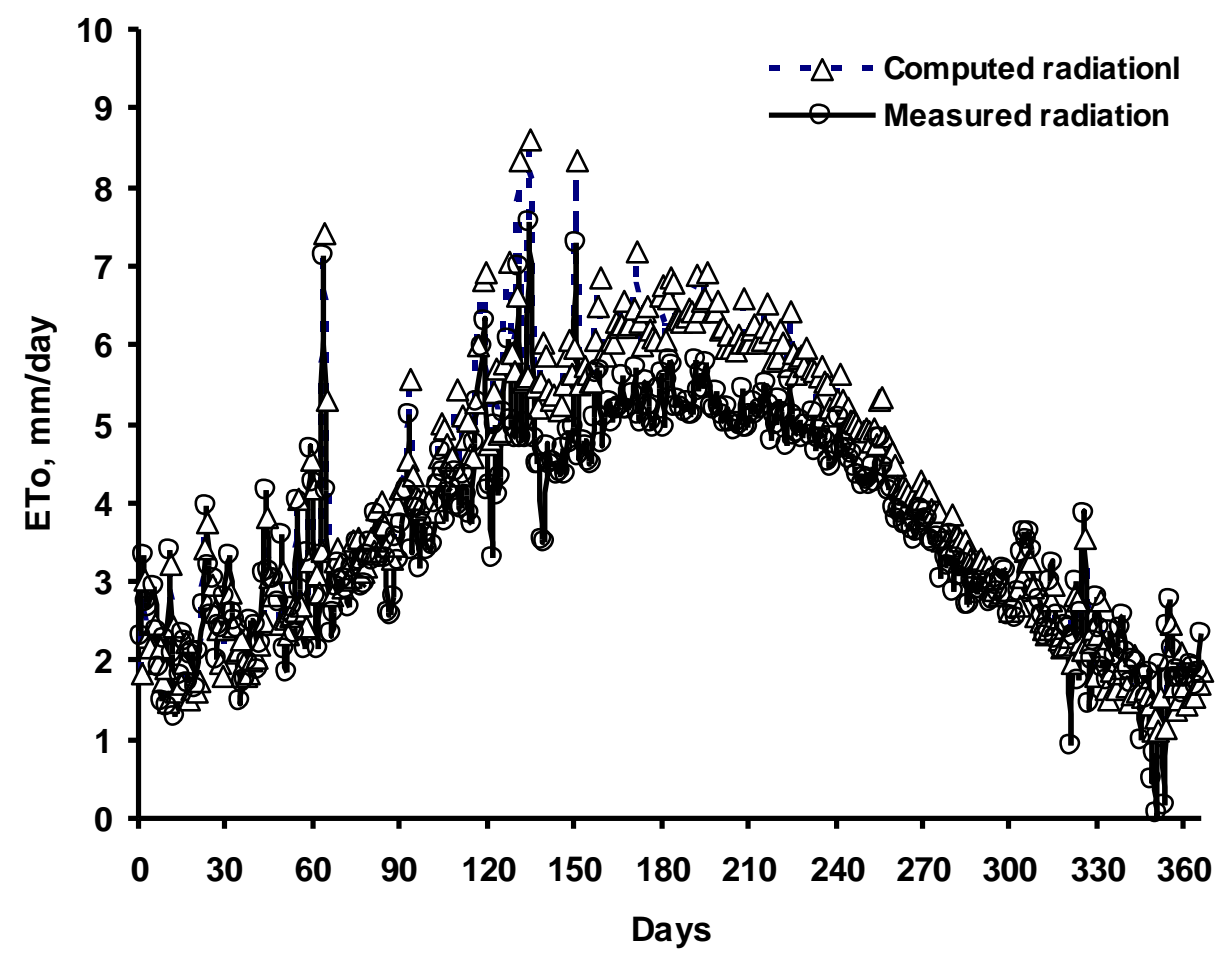

Fig. (8): Daily reference evapotranspiration (ETO) based on the computation model and measured solar energy 
Harmony between predicted solar energy and crop evapo-transpiration throughout four crop life was addressed as shown in Fig. (9). It shows the daily average solar energy computed by the model over Ber-Alabed $\left(33.0^{\circ}\right.$ long. and $31.45^{\circ}$ lat.), Egypt beside the measured ambient temperature, wind speed, and relative humidity by Met-One weather station were used to compute the evapo-transpiration for the four crops cotton, maize, wheat, and peas. Crop evapo-transpiration was calculated using the Penman-Monteith equation (Allen et al., 1998).

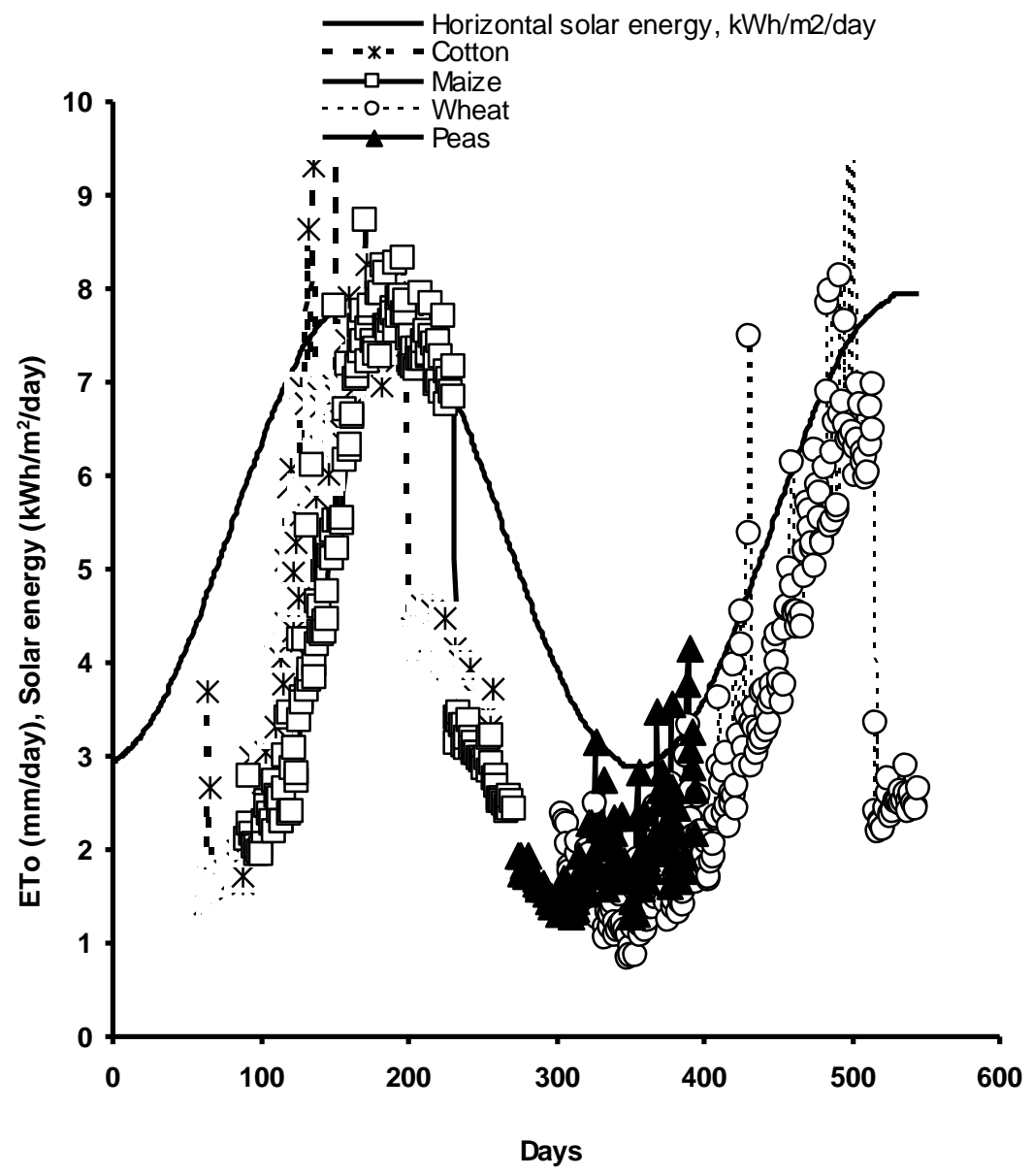

Figure (9): Relationship between predicted solar energy and crops evapotranspiratio (ETo) 
The harmony between the predicted solar energy i.e. pump flow rate to substitute the crop evapo-transpiration and crop evapo-transpiration was studied and plotted in Fig. (9). This criterion was achieved for cotton crop, where the coefficient of determination between the predicted solar energy and cotton evapotranspiration was computed to be 0.78 . Based on the harmony of the evapotranspiration and the available amount of solar energy to irrigate maize and wheat as it is shown in Fig. (9); the study found that, the photovoltaic pumps can be used beside other source to supply irrigation water, where their coefficients of determination were found to be 0.6 and 0.48 , respectively. Meanwhile, photovoltaic pump was not convenient to irrigate peas, where coefficient of determination between solar energy and peas evapo-transpiration was 0.09 .

\section{CONCLUSION}

The obtained results of this study support the following conclusions:

1. Daily average solar energy flux incident on a horizontal plane over Egypt (between $22^{\circ}$ to $32^{\circ}$ lat.N. and $24^{\circ}$ to $38^{\circ}$ long.E.) was computed by the developed program and found to be 5.72 $\mathrm{kWh} / \mathrm{m}^{2} /$ day.

2. The predicted solar radiation $\left(\mathrm{Wm}^{-2}\right)$ from the solar altitude angle $(\alpha)$ can be computed according to the following equation:

$$
G=13.23 \alpha+227.17
$$

3. The program was well estimated the solar energy over Egypt, whereas average deviation between the program and the measured data was $-3.5 \%$.

4. Incident solar energy over Egypt was decreased from south (with an average of $6.00 \mathrm{kWh} / \mathrm{m}^{2} /$ day) to the north (with an average of 5.41 $\mathrm{kWh} / \mathrm{m}^{2} /$ day).

5. The amount of incident solar energy over Egypt varies according to the season, for summer months it was $7.31 \mathrm{kWh} / \mathrm{m}^{2} /$ day at latitude of $22^{\circ} \mathrm{N}$, while it was $3.67 \mathrm{kWh} / \mathrm{m}^{2} /$ day for the same latitude in the winter months.

6. Variation in the amount of solar energy between the south and north locations of Egypt is higher in winter months than in summer months. 
7. Coefficient of determination $\left(\mathrm{R}^{2}\right)$ was found to be 0.94 for the reference evapo-transpiration determined (according to PenmanMonteith equation) using the predicted solar energy (compute from the program) and measured. .

8. The evapo-transpiration for some crops was studied according to the predicted solar energy from the program, the harmony between the crops evapo-transpiration and incident solar energy was studied. Cotton can be irrigated by photovoltaic pump $\left(\mathrm{R}^{2}=0.78\right)$, while this harmony was very low for peas $\left(\mathrm{R}^{2}=0.09\right)$.

\section{REFERENCES}

Allen R.G.; L.S. Pereira; D. Raes and M. Smith (1998). Crop evapotranspiration-guidelines for computing crop water requirements. FAO irrigation and drainage paper 56. Report of food and agriculture organization of the United Nations, Rome.

ASHRAE (2005). Handbook of Fundamentals "American Society of Heating, Refrigerating and Air Conditioning Engineers". New York, USA.

Duffie, J. A. and W. A. Beckman, (1991). Solar Engineering of Thermal Process Wiley - Interscine. New York, USA: 3-44.

Erbs, D. G.; S. A. Klein and W. A. Beckman (1983). Estimation of degree-days and ambient temperature bin data from monthly average temperature. ASHRAE J. 25(6): 60-5.

ESRA (Egyptian solar radiation atlas) (1991). New and Renewable Energy Authority, Cairo, Egypt.

Liu, B. Y. H. and J. R. C. Jordan (1963). The long-tern performance average performance of flat plat solar energy collectors. Solar Energy J., 7(-): 53.

Moharm, A. E. A. (1993). Utilization of solar energy for irrigation and its evaluation. (MSc) Thesis in Agicltural Eng. Dep, Fac. of Agr., Ain Shams U., Egypt.

Sayigh, A. A. M. (1987). The ISO-radiation map for the Arab region. Solar \& Wind Tec. J., 4(2): 163-177. 
Shaltout, M. A. and A. H. Hassen (1990). Solar energy distribution over Egypt using cloudiness from Metosat photos. Solar Energy J., 45(6): 345-351.

\section{الملخص العربي}

\section{التنبؤ بالطاقة الشمسية الساقطة على مصر للأغراض الزراعية}

أ.د. عادل سالم السيد*, د. أحمد على حسانين* و م. السيد محمد مصبلحى* هـ

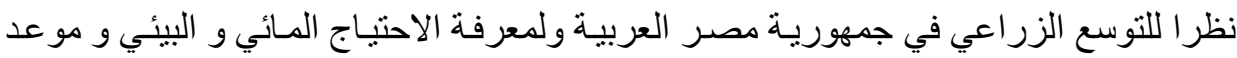
الزر اعة للمحاصيل المنزر عة في هذه المناطق تطلب الحاجة لرسم خريطة للطاقة السـاقطة على الطى الطي

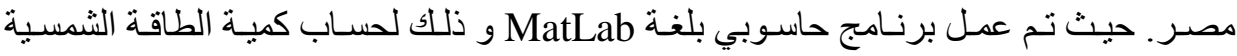

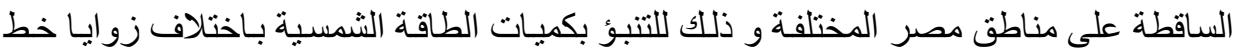

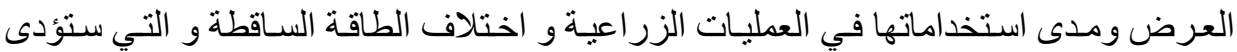

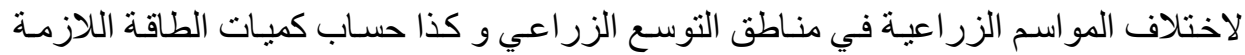

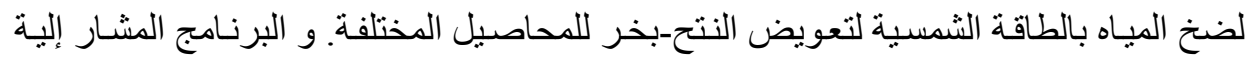

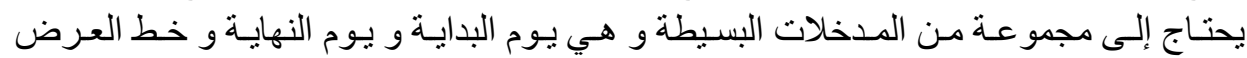

المطلوب. وقد تم اختبار البرنامج بقياس كمية الطاقة الساقطة على مناطق مختلفة من الجمهورية.

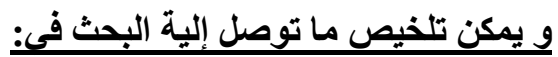

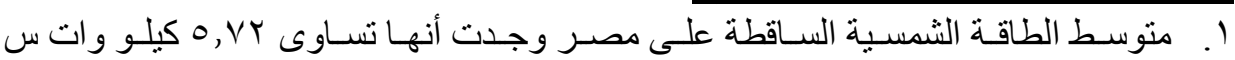
ا⿳艹 /

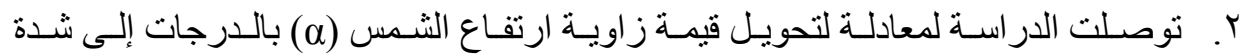

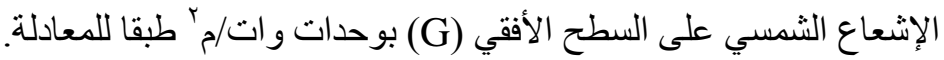

$$
G=13.23 \alpha+227.17
$$

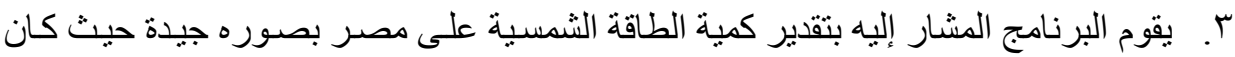

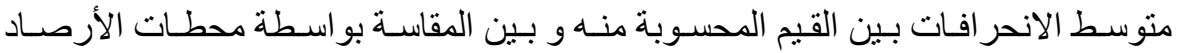

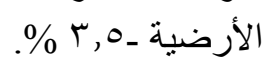

ع. . وجدت الدراسة أن كمية الطاقة الثمسية الساقطة على مصر تتدرج من الجنوب إلى الثمال

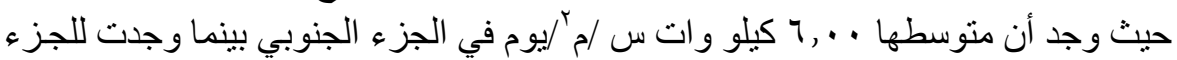

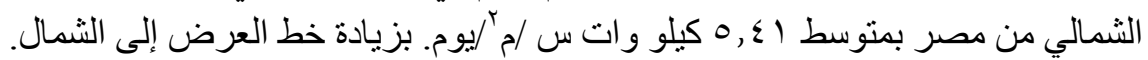

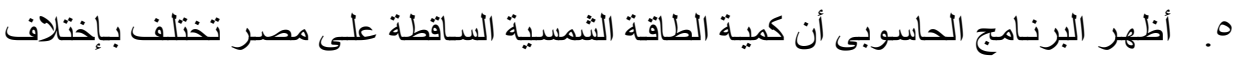

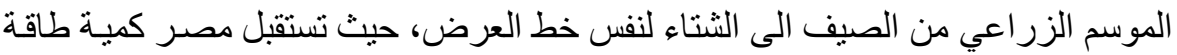

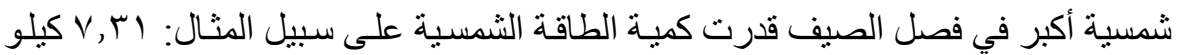

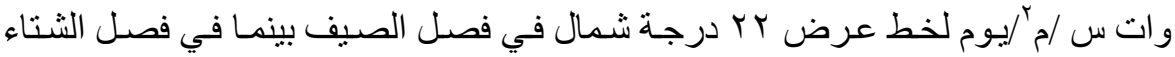

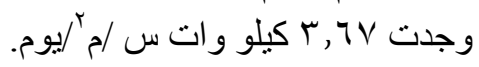


7. و يرجع ذلك لزيادة شدة الإشعاع الثمسي و طول ساعات النهار في فصل الصيف عنه في فصل الثتاء.

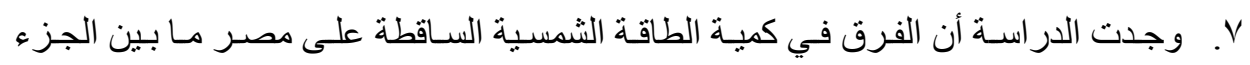

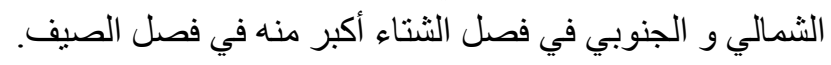

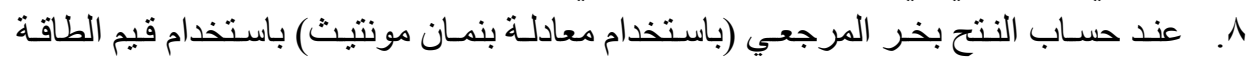

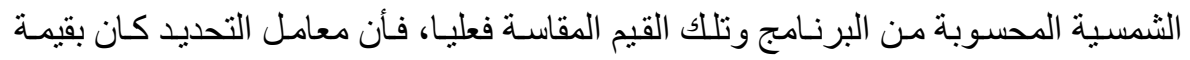
$\therefore, 9 \leq$

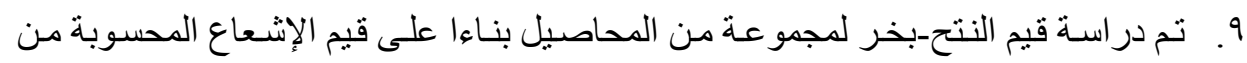

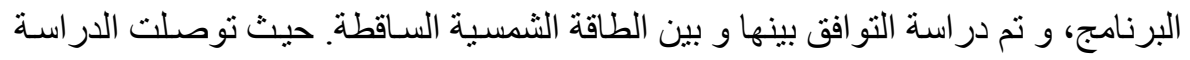

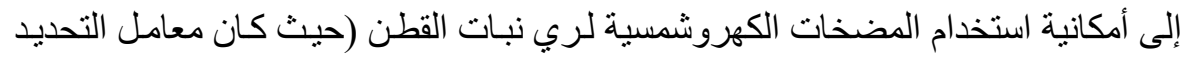

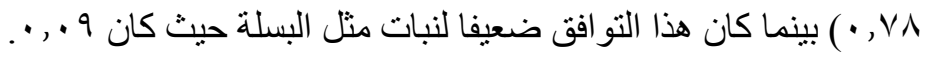

